\title{
Using Web 2.0 tools to teach reading biography
}

\author{
Rachmawati \\ Head of Library \\ Al Kausar Boarding School \\ Sukabumi, West Java \\ Indonesia
}

\begin{abstract}
Education development in Indonesia has begun to show its progress. Apart from improvement in the opportunity of basic education, the progress is also shown in the school libraries and the utilization of ICT in teaching and learning. Web 2.0 is the newest technology that has its impact on teaching and learning. Based on the literature and best practice in the developed country, some schools in developing countries have tried to apply this technology. Al Kausar Boarding School has applied Web 2.0 tools in teaching reading biography in Bahasa Indonesia for its grade seven students.
\end{abstract}

Web 2.0, reading biography, leadership

\section{Introduction}

Development of internet technology, which is known as Web 2.0, has happened so fast that within a short time has spread globally. The biggest consumers of this newest technology are young people, including students. They are often considered as digital natives. Any effort made by teachers to integrate the newest technology of the internet to teaching and learning activities, can attract students' interest in the lesson. The importance of this integration becomes clearer when we consider the preparation of pupils for the future. They are going to lead in the future, and it is our duty to prepare them for any changes they have to face.

\section{Education in Indonesia}

The System. There are three phases of formal education within our education system, namely primary, secondary and higher education. Primary education comprises of Primary School or Sekolah Dasar (six years) and Junior Secondary School or Sekolah Menengah Pertama (three years). This is a compulsory education that has to be provided freely for all Indonesian children at the age of seven to fifteen by the central and local government. Secondary school or Sekolah Menengah Atas is carried out in 3 years.

Most schools, about 84\%, run under the Ministry of National Education and the others run under the Ministry of Religious Affairs. The government plays the biggest role in providing education on the primary level, but on the secondary and higher levels, private institutions also play a significant role. 
The development. Although many complaints are still addressed concerning the implementation of education in Indonesia, it can't be denied that there's a significant progress in the development of education. Within the past two decades, the Indonesian society has witnessed the emerging of new 'good' schools. These schools offer an improved curriculum which combine or adopt international standards or any system from a developed country. These can be national plus schools, boarding schools, schools with international standards or so-called excellent schools (sekolah unggulan). They equip themselves with better facilities and employ highly professional staff.

The growing number of those schools indicates that there is a real market for quality education in Indonesia (Buchori, 142). People from middle to high social classes, who live well and usually work or live in an international environment, want their children to have a better education. They want their children to be fluent in Indonesian and English, acquire literacy in science and technology, have knowledge of social studies and history, be conversant about current issues, have competence in the fine arts and be able to present themselves in a polite and convincing manner. (Buchori, 153). These parents don't believe that the existing education system can provide such expectations. In the case of parents who send their children to a good boarding school, they want their children to be educated in a safe and conducive environment. The reason for that is usually intrinsic; such as a busy schedule for parents, divorced parents or expecting more independent children.

School Libraries. In 2003, the Government issued Law No 20/2003 on the National Education System. This law complemented with the Constitutional Mandate to allocate at least $20 \%$ of the National Expenditure for education. This has strengthened the status of school libraries. It states that every elementary, junior high school and senior high school or vocational school must have its own library. The number of school libraries has also increase.

The number of school libraries in Indonesia

\begin{tabular}{|l|l|l|l|l|}
\hline No & Type of school & $1999-2000$ & $2003-2004$ & $2007-2008$ \\
\hline 1 & Elementary school & 7.613 & & 78.422 \\
\hline 2 & Junior High School & 2.901 & 14.118 & 25.386 \\
\hline 3 & Senior High School & 2.104 & 5.598 & 14.781 \\
\hline
\end{tabular}

Every quality school can be assured to have a good or proper library. School librarians, whether professional or paraprofessional, are hired. Two associations were formed, FPSI and APISI. FPSI or Forum Perpustakaan Sekolah Indonesia was formed in 2002 and facilitated by the National Library. The members are mostly from public schools. APISI or Asosiasi Pekerja Informasi Sekolah Indonesia, on the other hand, was formed by school librarians from private schools in 2006. They need an association to accommodate their professional development.

In public schools, the library is managed by a teacher as library coordinator and one or more administrative staff. Most of them don't have any educational or professional background in librarianship. Professional school librarians are only hired by a few good schools. With this background, it is understandable that they have different concerns about their profession.

ICT in Education. With better facilities, schools can keep up with the advance of technology. International schools, national schools or other excellence schools definitely are equipped with good ICT facilities. As for public schools, the Government through the 
Directorate of Secondary Education provided a block grant to some schools to build or improve their ICT facilities. The Ministry of Communication and Information also helped through "One School One Lab-Computer" (OSOL) Project. There are also some other activities initiated by non-government bodies to support the use of ICT in schools such as Millennium Internet Road Show and Healthy Internet Movement.

\section{Al Kausar Boarding School}

Al Kausar Boarding School is one example of an excellent school. This is an alternative education for students whose parents are busy or simply just want a holistic and integrated education for their children. The school has founded in 1997. It is located in a rural area in Sukabumi, West Java, about $30 \mathrm{KM}$ from Jakarta.

Vision. The aim of the school is to become the best school that generates future leaders with Islamic values, are literate in science and technology, skilful and independent. $\mathrm{Al}$ Kausar offers three types of Excellences in the education of the students;

1. Islamic Values,

2. Science and Technology literacy and

3. Skills, independency and leadership.

Curriculum. The school applies the National Curriculum and integrates Islamic values, leadership and life skills in learning-teaching activities as well as in implanting those values in the daily life at the dormitory.

Al Kausar has its own paradigm about life-skills for the students. It emphasizes on the following points:

1. happy: learning activities are designed to attract students' interest

2. full actualization: learning is meant to be self actualization of teachers and students

3. useful: what is learned is useful for today and/or in the future

As the school's vision is to generate future leaders, the learning process we try to implement has the following leadership principles:

1. Understanding self

2. Communication

3. Getting along with others

4. Learning to learn

5. Decision making

6. Managing

7. Working with groups

All above values, i.e. Islam, leadership and life-skill, should be incorporated into lesson plans designed by teachers.

Students. The Al Kausar Boarding Campus is home to SMP Internat Al Kausar (Junior High School) and SMA IC - Al Kausar (Senior High School). The population of the school is 89 students which live in 3 dormitories. They come from different parts of Indonesia.

Until 2007, this school was only for boys. Along with the school development, we have begun to accept girls for the SMA level (grade X) in 2007. This year, we have opened registration for girls on the SMP level (grade 7). 


\section{Web 2.0}

When teachers educate students, it means that they are preparing their pupils for the future. In order to achieve this goal, they also have to be familiar with the advancement of the current technology. Web 2.0 is just one example of the newest technology that begins to impact on education

Web 2.0 refers to an improved phase of the internet that has been growing for almost 20 years. It is a term used to describe development of the Web which provides emphasis on the use of the web to improve collaborative and communication services, as opposed to a previous environment in which the Web was used primarily as a one-way publishing tool. (UKOLN, 2009). Many people are still debating the term but the differences are obviously clear. The key characteristics of Web 2.0 services are:

- Network as a platform: Rather than having to install software locally, Web 2.0 services allow application to be hosted on the network

- Always beta: Since Web 2.0 services are available on the network; they can be continually updated to enhance their usability and functionality.

- Culture of openness: A key benefit of Web 2.0 is provided by allowing others to reuse your content and you to make use of others' content.

- Tagging: Rather than having rely on the use of formal classification systems (which may not be meaningful to many users) tags can be created by users.

- Embedding: many examples of Web 2.0 services allow the content to be embedded in third party Web sites, blogs, etc. (UKOLN, 2009)

The use of Web 2.0 in Education. Young people are often considered digital natives. They are already familiar with some popular web 2.0 tools, especially the social networking sites. Using this technology for teaching and learning is like speaking in their language. Steve Hargadon suggests some educational benefit of Web 2.0 as follows:

- Engagement. Web 2.0 has the power to impact teaching and learning in ways that engage today's students in an interesting and relevant use of technology (Landa, 2008). One of the distinctive features of Web 2.0 is content creation. Hargadon further wrote that the engagement is in the act of content creation.

- Authenticity. When students write and create the content on the web, there is a real audience to test whether they are communicating their thoughts well.

- Participation. Even when still young, students can participate in contributing to the world's body of knowledge. It can be done when they write a report on any project on the web

- Openness and access to information.

- Collaboration. Wiki is a popular example of collaboration work on the web. 
- Creativity. Many Web 2.0 tools can arouse regular students’ creativity.

- Passionate interest and personal expression.

- Discussion. Another great feature of Web 2.0 is the discussion forum, which provides an environment for learning how to actually talk about things.

- Asynchronous contribution.

- Proactivity. Web 2.0 inherently rewards the proactive learner and contributor.

- Critical thinking.

Using Web 2.0 for teaching and learning within a K-12 situation is not without obstacles. It requires teachers to learn many new things and think carefully how to integrate them into the appropriate lesson and students have to be guided. They maybe technologysavvy but not information savvy.

\section{Using Web 2.0 tools to teach reading biographies}

Based on the above literature review, I believe that using web 2.0 tools can foster students' engagement in learning. I found no studies on the use of web 2.0 tools in teaching and learning activities in schools in Indonesia, although I found a few teachers' blogs that post their experience in using blogs in their lesson.

In this part of paper, I will describe the project we have done in using web 2.0 tools for teaching. I had the idea to implement this when a teacher told me about her plan to begin the reading unit in Bahasa Indonesia, wondering what strategy could be used this time. Reading can be a boring unit for seventh grade boys who love internet so much. Incorporating our school values, namely Islam, leadership and life-skills, make this unit an interesting challenge. We added technology content, web 2.0, to foster students' engagement. Together we arranged a collaboration for a project we called Biography Project.

Background. Before I further describe the implementation of the project, I think it is necessary to explain the background. Reading biographies was chosen to apply intensive reading and scanning. Biographies are usually written by prominent people in our society. Not only they talk about the dates and events, they also mention their success, thoughts or life vision. By reading their biography, we expect students to learn from it and be inspired by it. We can also guide students to reflect on their selves and understand them better.

We found this very suitable for our students' condition, both psychologically and physically. The seventh grade students, who are participants in this project, are between 12 and 13 years old. There are 21 students in two classes. They are all male students, as this year we only received male students in our school. They come from families of middle to high socio/economic status. It is not easy to apply our school values in their daily life. They have just begun their teenage life and try to adjust to a new life in a boarding school, far from their families. Most of them are familiar with the use of computers and internet, but mostly with recreational features such as games. During this first year at school they become more familiar with basic tools such as programs in Microsoft office.

Our school provides internet service only in the library. We have a policy about acceptable use of computer and internet in the library. All students are given this in writing 
along with a form they have to sign after having read, understood and agreed to it. We also put this information on a poster in the internet room. The seventh grade students are the heavy users of this service. They try to use it as often as possible. Unfortunately, these seventh graders have not got enough provision on information literacy.

The curriculum standard we want to achieve in this project is as follows:

Standard competence : Students will understand written expression through intensive reading and scanning

Basic competence : Students will look for a set of good examples from biographies

Special contents

- Life skills:

o Students will analyze a positive contribution they can make for their surroundings (useful)

o Students will actualize themselves maximally in a unique way (full-actualized)

- Leadership:

o Students will learn how about steps undertaken by the prominent people in achieving their success (decision making).

o Students will understand and develop positive traits of themselves (understanding self)

- Islamic values: the best human being is one who is useful to others

- ICT: the use of web 2.0 tools (wiki and glogster)

Structure of the project. This is a project of Bahasa Indonesia (Indonesian Language). The teacher took full responsibility in teaching in the classroom and I, as a librarian and coteacher took responsibility in the introduction of Glogster and preparing wiki pages for this project. As for assessing the project, there was a joint assessment by both of us. There was also peer assessment among the students.

This project consisted of several activities, both online and offline. The project began by viewing a biography film as an introduction to what a biography is. In the next lesson, the Bahasa Indonesia teacher gave the students an assignment to read a biography of a prominent Muslim in history. The students were also encouraged to read other biographies of their chosen person. This assignment was followed by a writing assignment to summarize what they have read and an oral presentation.

After those activities, there was a reflection to map their own selves; about who they are, what they want to achieve in the future, what are the positive or negative traits they have and a short biography of their life so far. The teacher guided them to make a mind-map.

Based on the mind-map, the students made a poster in Glogster after the introduction of this tool had been given by the librarian.

Timeline of the project

\begin{tabular}{|l|l|}
\hline Lesson Plan & Time \\
\hline Viewing a biography film & March $3^{\text {rd }}, 2009$ \\
\hline Reading biography book & March $4^{\text {th }}, 2009$ \\
\hline Make a summary of a biography of a certain person & March $5^{\text {th }}-9^{\text {th }}, 2009$ \\
\hline Make an oral presentation about that person & March $10^{\text {th }}, 2009$ \\
\hline
\end{tabular}




\begin{tabular}{|l|l|}
\hline Make a mind-map about their own profile & March $11^{\text {th }}, 2009$ \\
\hline Introduction to Glogster & March $12^{\text {th }}, 2009$ \\
\hline Make an online poster on Glogster based on the mind-map & March $16^{\text {th }}-26^{\text {th }}, 2009$ \\
\hline Presentation of the poster & March 31st, 2009 \\
\hline
\end{tabular}

Project implementation. In reality, things didn't run as smoothly as we planned. The internet connection was interrupted for more than two weeks. Our school uses broadband internet connection, but sometimes there are disruptions caused by either the electrical service or bad telephone connection. Normally, the disruption lasts no more than a few hours but, the end of March, the internet connection was very slow for students to log onto Glogster websites. As we are in a boarding, I could arrange an extra class in the evening to continue our project. But even in the evening the connection was not better.

Another difficulty we found was to keep the students concentrated on their work. When doing their work online, they tended to open a few tabs or windows on the browser. Because Glogster uses many graphics, it takes time to open and work on it. The students didn't have enough patience to wait for it. Instead they were browsing to other things which only made it longer for Glogster to work.

After some extra time and school breaks, we finished the project on May $6^{\text {th }}$. We held the presentation of the students' work on Glogster in the internet room in the library. Until the last minute of the presentation, some students still tried to revise their work to make it better. Some of their works were very praiseworthy. They were beyond our expectations.

I summarize the evaluation of their work as follows:

- Glogster use. Most of the work used almost all the features of the Glogster. Two students included sound (music) in their work.

- Creativity. The way they presented and used their creativity was quite amazing.

- The language. Unfortunately the language they used was not as we expected. Some used informal language as if speaking to a friend. In Bahasa Indonesia, the use of informal language or colloquial language is quite different and sometimes considered improper in our society.

- The religious content (Islamic value). Most of the students could identify the Islamic values failed to excerpt it from the biography they had read. It seems like there was no connection between what they have read and their current condition.

- Leadership content. Only a few students took prominent Muslims in history as their life example. Instead they took famous football players as their idol. They could identify the good and bad sides of their personality but still don't know how to realize their dreams into specific steps.

- Life-skill content. Students could present their ideal dream, to be a useful person in society, and present themselves creatively using the glogster features.

- Wiki use. I created a wiki page for this project, asked the Bahasa Indonesia teacher to be the editor and invited some students to be writers. I encouraged the teacher and the students to create new pages or give comments. This is another characteristic of web 2.0, collaboration. Unfortunately, neither teacher nor students use this feature a lot. Only two students create pages to post their glogster. The teacher used only the page I created before to add some more information. No comment was posted in the wiki 
pages or in the glogster, but when a student presented his glogster, the others gave comments.

- Presentation skills. I evaluate the students' presentation skills both from the way they present their work orally and from the glogster they made. In glogster they present themselves freely, using graphics, words and colours they like. They made wonderful works. On the other hand, when they had to give an oral presentation, they tended to be shy and not very convincing. Only some students did it confidently.

\section{Conclusion}

Upon the completion of the project, I come to the conclusion that applying web 2.0 tools in teaching and learning in a K-12 situation fosters students'engagement in learning and boosts their creativity. However, we need to carefully design the teaching and consider any difficulties we may face and be prepared for them.

\section{References}

Anderson, Paul. (2007). What is web 2.0? Ideas, technologies and implication in education. JISC Technology and Standards Watch, Feb. 2007. Retrieved May $12^{\text {th }}, 2009$ from www.jisc.ac.uk/media/documents/techwatch/tsw0701b.pdf

Buchori, Mochtar. (2001). Notes on education in Indonesia. Jakarta : The Jakarta Post in cooperation with The Asia Foundation

Fairbanks, Elizabeth Mary. (2008) Student collaboration using web 2.0 technologies. Arizona State University . Retrieved May $12^{\text {th }} 2009$ from www.lulu.com/items/volume_63/2377000/2377299/1/print/2377299.pdf

Hargadon, Steve. (2008). Moving toward Web 2.0 in K-12 Education. Retrieved February 2, 2009 from http://www.stevehargadon.com/2008/10/moving-toward-web-20-in-k-12-education.html

Landa, Rebecca T. (2007). Web 2.0 - A future in teaching and learning. Retrieved January 30, 2009 from http://gemini.utb.edu

Muslimin, Sutrisno. (2009). Boarding School : Solusi Pendidikan untuk Melahirkan Pemimpin Masa Depan. Retrieve May 12 2009 from http://sutris02.wordpress.com/2009/03/23/boarding-school-solusipendidikan-untuk-melahirkan-pemimpin-masa-depan/

Muslimin, Sutrisno. (2008). Problem dan solusi pendidikan berasrama. Retrieve May $12^{\text {th }} 2009$ from http://sutris02.wordpress.com/2008/09/08/problem-dan-solusi-pendidikan-berasrama-boarding-school/

Naslund, Jo-Anne and Giustini, Dean. (2008). Towards School Library 2.0: An Introduction to Social Software Tools for Teacher Librarians. School Libraries Worldwide Vol. 14 No.2, 55 - 88. Retrieved February 2, 2009 from http://www.iasl-online.org/pubs/slw/july08.htm

Prawiradilaga, Dewi Salma, \& Siregar, Eveline. (2004). Mozaik teknologi pendidikan. Jakarta : Kencana in cooperation with Universitas Negeri Jakarta

Setyautami, Maya Retno Ayu (2008). Blog Sebagai Media Pembelajaran Alternatif. Paper of Kompetisi Karya Tulis Mahasiswa Bidang Pendidikan .

The National Library of Indonesia (2008). Library development in Indonesia : a Country report. Retrieved May $12^{\text {th }}, 2009$ from www.ndl.go.jp/en/cdnlao/meetings/pdf/CR2008-Indonesia.pdf

UKOLN. (2009). An introduction to Web 2.0. Retrieved May 21 $1^{\text {st }} 2009$ from www.ukoln/ac.uk/culturalheritagedocuments/briefing-1/html.

Yuhetty, Harina. (n.d). ICT and Education in Indonesia. Retrieved May 13 ${ }^{\text {th }}, 2009$ from http://gauge.ugakugei.ac.jp/apeid/apeid02/papers/Indonesia.htm

\section{Biographical Notes}

Rachmawati is a librarian in Al Kausar Boarding School since 2001. She's a district coordinator of APISI (Association of Indonesian School Information Professionals). Her main interest is to promote Information Literacy among her colleagues 


\section{Statement of Originality}

This statement certifies that the paper above is based upon original research undertaken by the author and that the paper was conceived and written by the author(s) alone and has not been published elsewhere. All information and ideas from others is referenced. 